\title{
Mineralogy and stable isotope geochemistry of the Ab Ask travertines in Damavand geothermal field, Northeast Tehran, Iran
}

\author{
Somayeh Rahmani Javanmard, Faramarz Tutti* \\ Department of Geology, College of Science, University of Tehran, Tehran, Iran
}

\section{Safieh Omidian}

Department of Geology, Faculty of Science,

University of Sistanand Baluchestan, Zahedan, Iran

\author{
Mohsen Ranjbaran \\ Department of Geology, College of Science, \\ University of Tehran, Tehran, Iran
}

The Ab Ask mineral springs are located $85 \mathrm{~km}$ northeast of Tehran, in the southern range of the Damavand volcano. Deposits of these calcareous springs are mainly precipitated as travertine. Petrographical, mineralogical, and stable isotope studies were conducted on different types of travertine to determine their genesis and factors that govern carbonate precipitation. Based on sedimentation consequence and lithofacies these travertines are categorized as first type (fresh travertine), second type (fissure-ridge, dam, and cascade), and third type (laminated) travertines, illustrating a specific condition of formation, deposition and diagenesis. Combined XRD and microscopic investigations show that the Ab Ask travertines are is composed of about $95 \%$ calcite and a minor amount of quartz along with iron oxide impurities. The origin and transport of springs water from which travertine was precipitated are elucidated by ${ }^{13} \mathrm{C}$ and ${ }^{18} \mathrm{O}$ isotopic studies of the travertines. $\delta^{18} \mathrm{O}$ and $\delta^{13} \mathrm{C}$ values of travertines increase (from -13.0 to $-6.3 \%$ VPDB and from 6 to $9.8 \%$ VPDB, respectively) with increasing distance from the spring orifice. This significant increase is attributed to temperature decrease, rapid degassing of $\mathrm{CO}_{2}$, and biological activities. It seems that $\mathrm{CO}_{2}$ content of these fluids may have originated from limestone decarbonation. Based on the integrated petrographic and stable isotope study, the Ab Ask travertines can could be thermogenic in origin.

Key words: Ab Ask, Damavand, hot springs, stable isotope, travertine

Addresses: S. Rahmani Javanmard, F. Tutti, S. Omidian, M. Rajnbaran e-mails: Somayeh.rahmani@khayam.ut.ac.ir, ranjbaran@khayam.ut.ac.ir, somidian@khayam.ut.ac.ir *Corresponding authors' e-mail: tutti@khayam.ut.ac.ir

Received: October 4, 2012; accepted: December 25, 2012 


\section{Introduction}

Travertine is a type of freshwater limestone deposited from cold or hot spring waters, or less commonly from percolating waters (Wyatt 1986). The term travertine is also commonly used in a broader sense to refer to all non-marine limestone formed under climatic controls in streams, lakes, springs, and caves (e.g. Sanders and Friedman 1967; Viles and Goudie 1990; Pentecost and Viles 1994), while tufa refer to limestone precipitated in cool or near-ambient temperature water and characterized by high micro- and macrophyte, bacteria, and invertebrate content (Ford and Pedley 1996). In general, travertine is composed of mainly calcite with low-Mg content, or less abundantly, of aragonite (Guo and Riding 1992; Fouke et al. 2000; Pentecost 2005). Physical processes such as agitation of the water or variations in flow related to functional karstification of aquifers (Martin 1988) and biological processes of certain microorganisms, such as algae and bacteria (Casanova 1986), can affect travertine precipitation and facies. Based on the origin of carbon dioxide, travertine can be divided into two classes (Pentecost and Viles 1994; Pentecost 2005). The kind which obtains $\mathrm{CO}_{2}$ mainly from organic activity in the soil is named meteogene travertine while thermogene travertine acquires $\mathrm{CO}_{2}$ from thermal processes, including magmatic degassing or decarbonation of limestone during thermometamorphic processes (Pentecost and Viles 1994; Ford and Pedley 1996; Minissale et al. 2002). Thermogene travertine is usually massive and contains less organic materials than meteogene travertine, and is essentially found in regions with recent volcanic or high tectonic activity. The worldwide distribution of travertine and its genesis from hot springs have been widely described by many investigators: in the Pannonian Basin by Schweitzer and Scheuer (1995) and Kele (2009), in the Yellowstone area by Chafetz and Guidry (2003), in Turkey by Altunel and Hancock (1993a, b, 1994), in France by Pentecost (1991, 1995), in the Turkana Basin by Renaut et al. (2002), in the Colorado Plateau by Shipton et al. (2004), in Rapolano Terme (Italy) by Brogi and Capezzuoli (2009), in the Betic Cordillera by Martinez-Diaz and HernandezEnrile (2001), etc. A detailed stable isotope study on the Pamukkale travertine was carried out by Kele et al. (2011).

The principal purpose of this work is to carry out for the first time a detailed study on representative samples of the $\mathrm{Ab}$ Ask travertine in the vicinity of Damavand volcano, which is in turn a well-known volcano from a global tectonics and volcanic point of view. Petrography, combined with the $\mathrm{C}$ and $\mathrm{O}$ stable isotope studies, has been performed on this travertine in order to define the origin of $\mathrm{CO}_{2}$ in the waters from which these carbonates were deposited. The present study could, to some extent, provide valuable information on the paleoenvironment of travertine precipitation and determine the local processes that influence carbonate lithology, as well as elucidate the relationship between the thermal springs and volcanic activities of Damavand through time. 


\section{Geologic settings}

The Ab Ask travertine is located around the hot springs in a village of the same name southeast of Damavand volcano, northeast of Tehran (Fig. 1). The exposed geologic formations in the area were studied by many geologists (e.g. Allenbach 1966) and consist of Paleozoic and Mesozoic sediments, mainly limestone, shale and sandstone, as well as Tertiary-Quaternary rocks including pyroclastics, ash falls and lava flows (Fig. 1). This area is located in the middle of the Central Alborz, which is a tectonically very active zone in the Iranian Plateau. Recent and active tectonics in the Alborz mountain range has been studied by many geologists (e.g. Tchalenko 1974; Ambraseys and Melville 1982; Berberian 1983; Alavi 1996; Jackson et al. 2002).

The structural architecture of the Alborz remains controversial issue. Axen et al. (2001) noted that several of the thrusts have normal separations and interpreted the assemblage as an asymmetrical, south-vergent, transpressional flower structure. Similarly, Jackson et al. (2002) and Allen et al. (2003) considered the Alborz to be a sinistral transpressional belt, where slip is partitioned between sinistral strike-slip faults and thrust faults. Alavi (1996) interpreted the Alborz as a thin-skinned fold-and-thrust belt that has formed a complex composite antiformal stack, which is cut by detachment and normal faults that drop the south Caspian down relative to the Alborz. There are copious faulting and folding activities within it. To identify the major ranges of fractures and faults in studied region, Aster Remote Sensing satellite image studies were performed (Fig. 2). These studies showed that the best linear feature exposures are visible in the region of the 4,3,1 band combination in the RGB environment. Two linear trends, ESE (for major lineation) and ENE (for minor lineation, but more dispersion) were identified. Concentrations of these lineations in the Ab Ask region were attributed to the multiple fractures in this area. These fractures are assumed to be the cause of the formation of hot water springs and travertine deposition.

\section{Descriptions of the Ab Ask springs}

Temperature, $\mathrm{pH}, \mathrm{EC}$ and TDS data of the four hot springs are summarized in Table 1 (Shemshaki et al. 2008). The hot springs of the Ab Ask area are slightly acidic $(\mathrm{pH}=6-6.41)$ and have temperatures ranging between $23^{\circ} \mathrm{C}$ and $30^{\circ} \mathrm{C}$, while EC varies from 1.39 to $3.65 \mathrm{mS} \mathrm{cm}^{-1}$ and TDS ranges from 1.81 to $2.79 \mathrm{~g} / \mathrm{L}$. The EC values obtained for the Ab Ask springs $\left(1.39-3.65 \mathrm{mS} \mathrm{cm}^{-1}\right)$ fall in the range of thermogene waters (1-10 $\mathrm{mS} \mathrm{cm}^{-1}$; see Pentecost 2005).

\section{Sampling and methodology}

Based on travertine morphology and external lithofacies, 50 rock samples were collected in order to determine their mineralogical properties, and texture; among thm 16 samples were chosen for isotopic analyses. Thin section of rock 


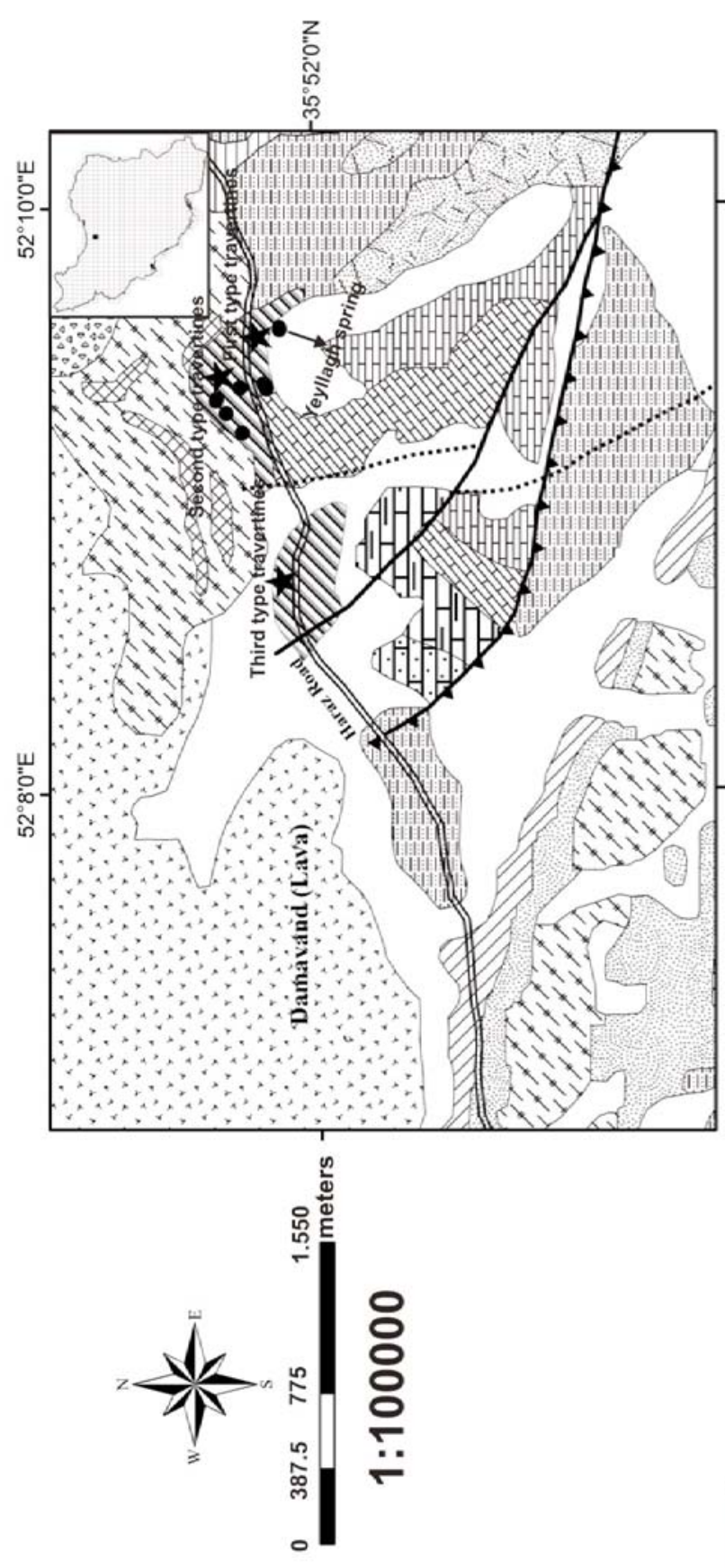

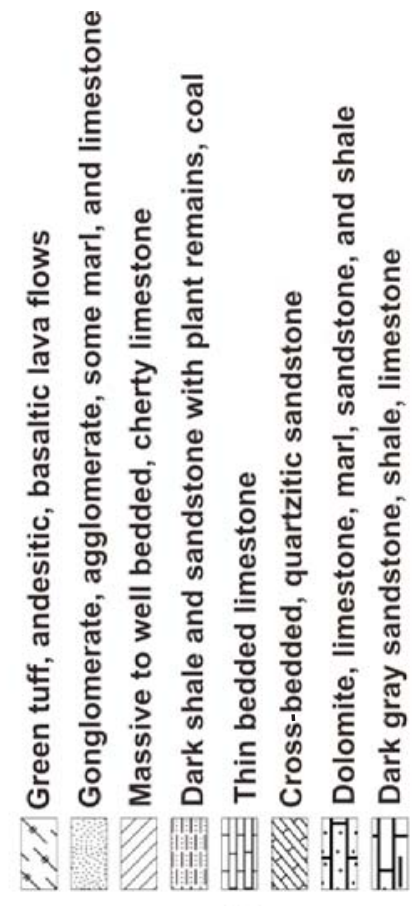

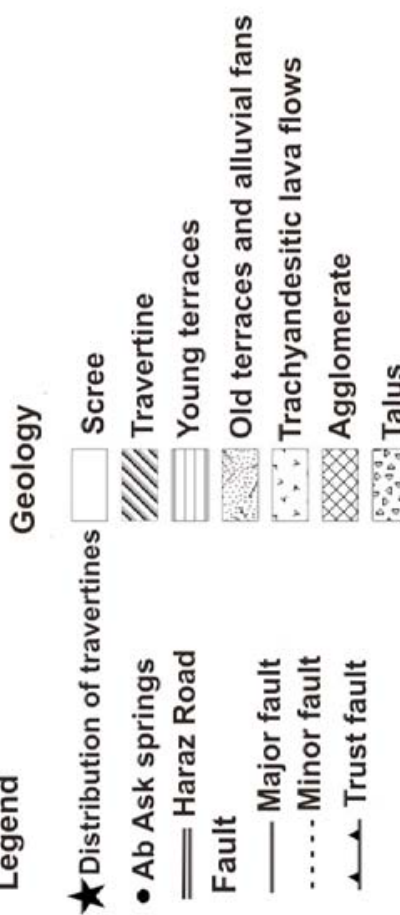


$\leftarrow$ Fig. 1

Geologic map showing the position of travertine deposits of the Ab Ask hot springs. (Allenbach and Shteiger 1966)

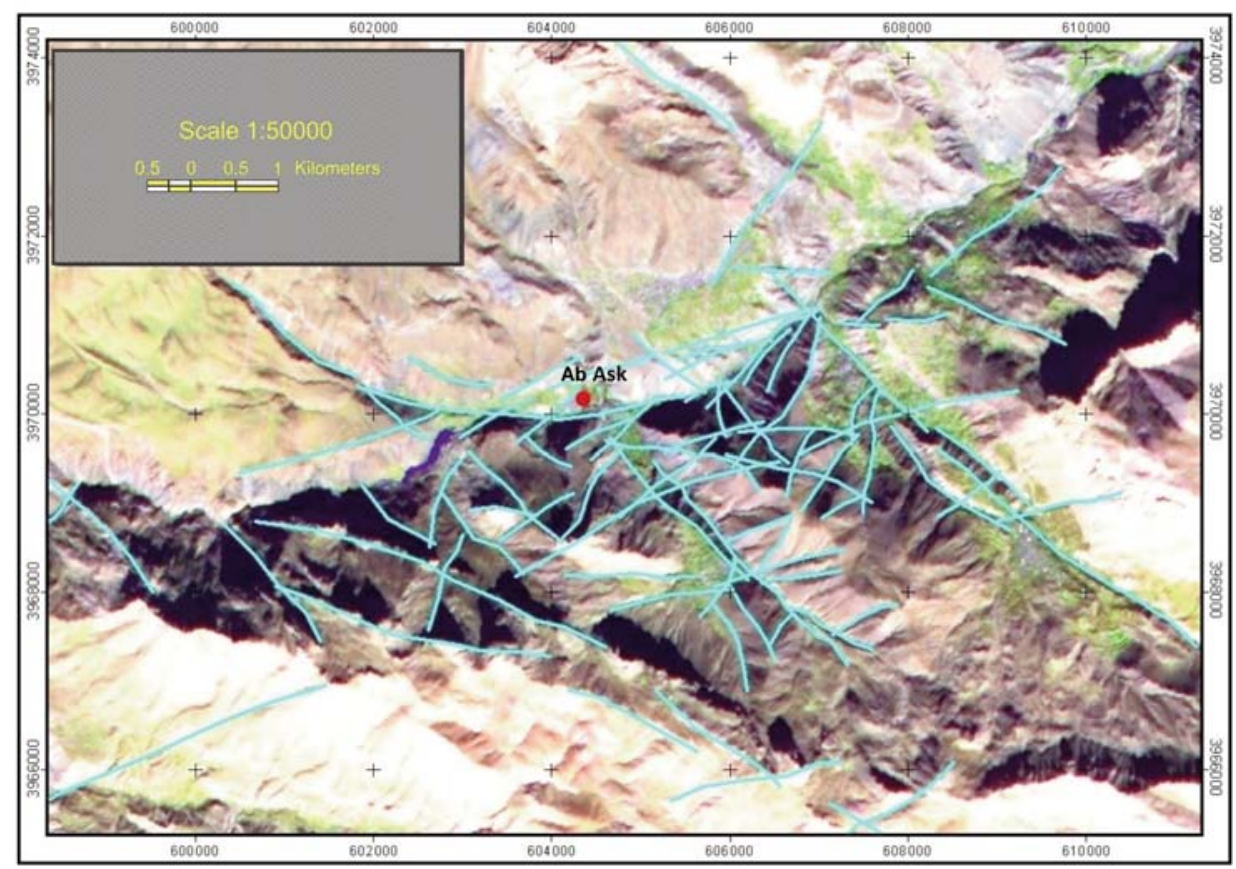

Fig. 2

Existing lineations in Aster satellite image with the 4,3,1 band combination

Table 1

Names and physical-chemical parameters of the Ab Ask Hot Springs

\begin{tabular}{|l|c|c|c|c|}
\hline Spring name & $\mathrm{T}\left(\mathrm{C}^{\mathrm{o}}\right)$ & $\mathrm{pH}$ & $\mathrm{EC}\left(\mathrm{mS} \mathrm{cm}^{-1}\right)$ & T.D.S $(\mathrm{g} / \mathrm{L})$ \\
\hline Zagh Spring & 29 & 6.41 & 3.65 & 1.82 \\
\hline Ghay Bal Spring & 23.4 & 6.28 & 1.39 & 2.79 \\
\hline $\begin{array}{l}\text { Mokhaberate } \\
\text { Spring }\end{array}$ & 29.2 & 6.38 & 3.64 & 1.81 \\
\hline Yeyllagh Spring & 30 & 6 & & \\
\hline
\end{tabular}

specimens were studied by polarized microscope and some selected samples were then analyzed by X-ray powder diffraction (XRD) with $\mathrm{Cu} \mathrm{K}_{\alpha 1}$ radiation at the Solid State Research Laboratory (University of Damghan), using a Hitachi S4160 Scanning Electron Microscope at the University of Tehran. The isotopic composition of the travertine was measured according to the method described 
in detail in Breitenbach and Bernasconi (2011). Approximately 100 micrograms of powder were reacted with $100 \%$ phosphoric acid at $70^{\circ} \mathrm{C}$ in a Thermo Fisher Gas Bench device connected to a Thermo Fisher Delta V mass spectrometer at the ETH Stable Isotope Laboratory (Zurich, Switzerland). The reproducibility of the measurements based on replicated standards was $\pm 0.05 \%$ for $\delta^{13} \mathrm{C}$ and $\pm 0.06 \%$ o for $\delta^{18} \mathrm{O}$. The instrument is calibrated with the international standards NBS19 $\left(\delta^{13} \mathrm{C}=1.95\right.$ and $\delta^{18} \mathrm{O}=-2.2 \%$ ) and NBS18 $\left(\delta^{13} \mathrm{C}=-5.01\right.$ and $\delta^{18} \mathrm{O}=-23.01 \%$ ) The isotope values are reported in the conventional delta notation with respect to VPDB (Vienna Pee Dee Belemnite). All analytical results are displayed in Table 3.

\section{Results}

\section{Mineralogy and petrography}

Microscope studies have shown that the studied travertine samples are mostly composed of calcite which was confirmed by the results of the powder X-ray diffraction technique (Table 2). Based on their sedimentation sequence and lithofacies, they can be divided into several groups and subgroups.

1.) First type travertine (stream channel deposits). These loose and porous deposits constitute nodular forms and thin layers with greenish surfaces (Fig. 3A). Their nodular shape may result from colonization by algae, especially cyanobacteria (Pentecost 2005). Microscopic studies show that they are composed of lublinite-like (acicular) crystals (Fig. 3B). The origin of these crystals could be associated with the late stages of cement formation (Gruszczynski et al. 2004). Lublinite-like crystals may have formed as a felt during evaporation when the bacterial-mat pond had been dried out (Folk et al. 1985). These crystals tend
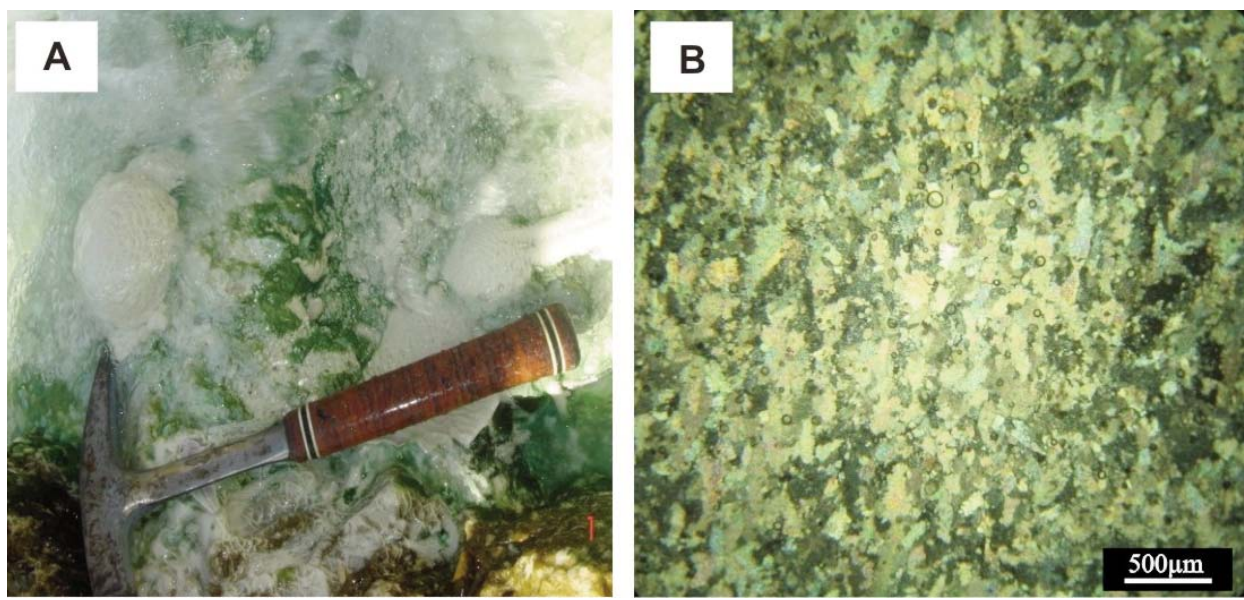

Fig. 3

The first type travertine described in the Ab Ask area. (A) Field photograph of first type travertine (B) Photomicrograph of lublinite-like (acicular) crystals (crossed polars) 


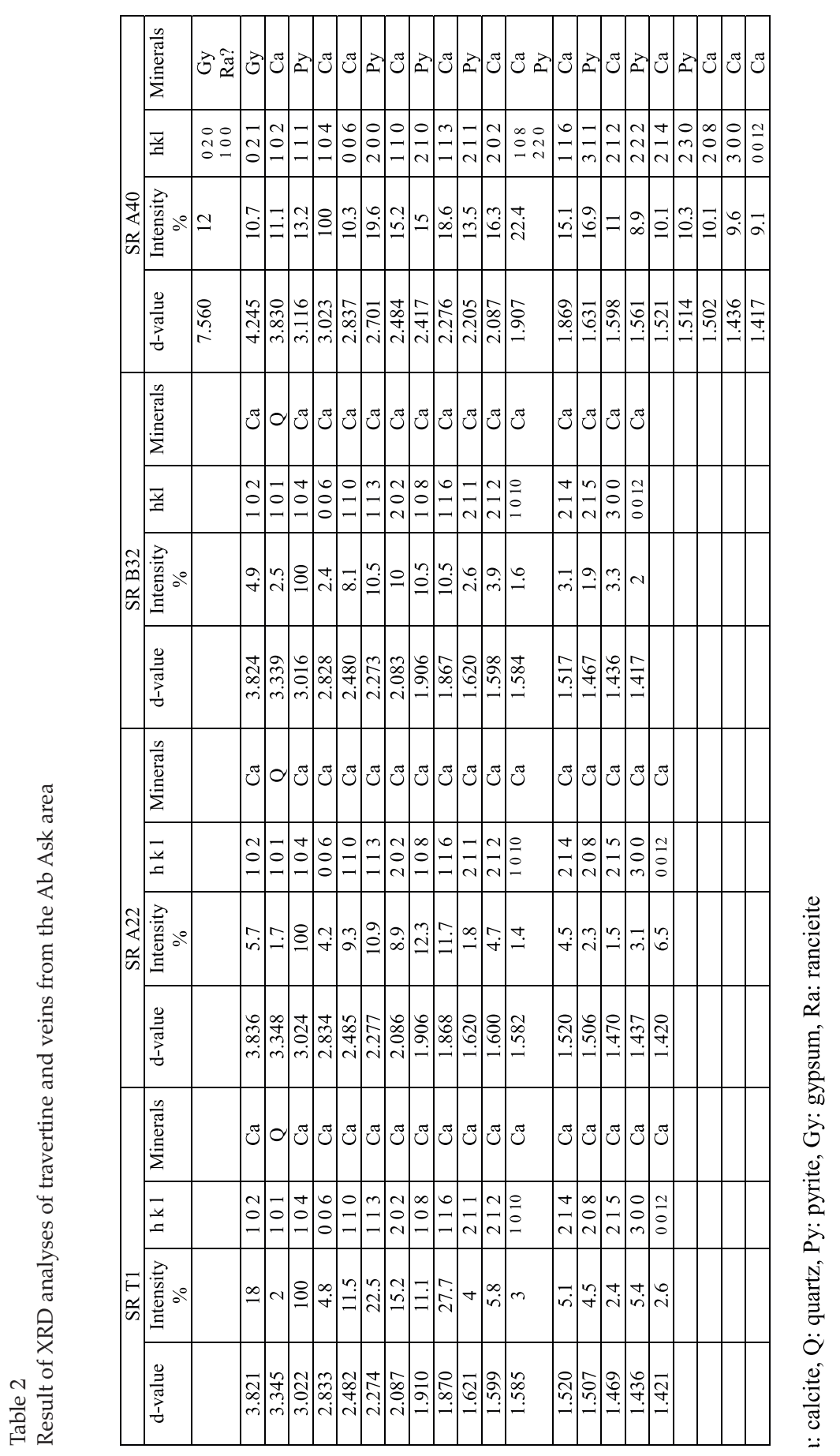


Table 3

Stable oxygen and carbon isotope data and recalculated $\delta^{13} \mathrm{C}\left(\mathrm{CO}_{2}\right)$ values of travertine and veins from the Ab Ask geothermal field

\begin{tabular}{llccrc}
\hline Sample & $\delta^{18} \mathrm{O}_{(\mathrm{VPDB})}$ & $\delta^{13} \mathrm{C}_{(\mathrm{VPDB})}$ & $\delta^{18} \mathrm{O}_{(\mathrm{VSMOW})}$ & $\delta^{13} \mathrm{C}_{(\mathrm{CO} 2)}$ & Description \\
\hline SR T1 & -12.58 & 6.61 & 18.92 & -2.56 & First type travertine \\
SR M 13 & -13.02 & 6 & 17.43 & -3.3 & Second type travertine \\
SR Z 14 & -12.59 & 6.48 & 17.88 & -2.72 & Second type travertine \\
SR A 22 & -11.84 & 6.72 & 18.65 & -2.43 & Second type travertine \\
SR A 12 & -11.08 & 7.35 & 19.43 & -1.68 & Second type travertine \\
SR A 15 & -10.13 & 7.54 & 20.41 & -1.45 & Second type travertine \\
SR A 60 & -9.57 & 7.92 & 20.99 & -0.99 & Second type travertine \\
SR A 9 & -9.29 & 9.79 & 21.28 & 1.24 & Second type travertine \\
SR B 32 & -6.34 & 8.14 & 24.32 & -0.73 & Third type travertine \\
SR A 40 & -11.68 & 5.8 & 18.81 & -3.54 & Veins \\
SR A 4 & -12.8 & 5.16 & 17.66 & -4.30 & Veins \\
SR A 36 & -14.38 & 5.95 & 16.03 & -3.36 & Veins \\
SR M 14 & -12.88 & 5.97 & 17.58 & -3.33 & Cement (Secondary calcite) \\
SR D 13 & -12.62 & 6.06 & 17.85 & -3.22 & Cement (Secondary calcite) \\
SR A 52 & -7.86 & 6.4 & 22.75 & -2.82 & Cement (Secondary calcite) \\
SR A 32 & -6.73 & 7.96 & 23.92 & 0.94 & Cement (Secondary calcite) \\
\hline
\end{tabular}

mostly to be present in the meteoric-vadose zone, where the saturation index of carbonate is very high and the fluid flow is agitated (Nelson 1990). Based on XRD analysis these samples are mainly composed of calcite with a minor amount of quartz (Table 2).

2.) Second type travertine is of white to cream color and is commonly found as massive deposits in the area (Fig. 4A). Microscope observations show that they were not much affected by diagenesis, and significant amounts of mouldic, shelter and vuggy porosity have remained in rock specimens (Fig. 4B). Thin sections demonstrate that micrite, microspar and sparite are the major constituents of the rock (Fig. 4B). The microsparite and sparite calcite occurred as secondary calcite which commonly fills pores and is readily distinguishable from micrite. Since its formation, this type of travertine has been directly exposed to meteoric waters, allowing enough time for potential diagenetic alteration. However, some degree of diagenetic alteration is detectable by the presence of secondary or recrystallized calcite appearing in the vadose environment (Fig. 4B). Aggrading neomorphism of micrite into microsparite may be the result of algae and bacterial activities (Fluegel 1982). Because of aggradational neomorphism this travertine is heavier, harder, less porous and more massive than first type travertine. Recrystallization of any limestone takes place as the primary minerals equilibrate with their surroundings (Sunagawa 1990). Such changes may be driven by the polymorphic transformation of aragonite to calcite and/or the exposure of marine carbonates to meteoric water (e.g. Tucker and Wright 1990). Similar to Fall Creek Tufa (Rainey and Jones 2007) there is no indication in Ab Ask travertine that aragonite has ever been the primary deposit. Thus, the crystal size 

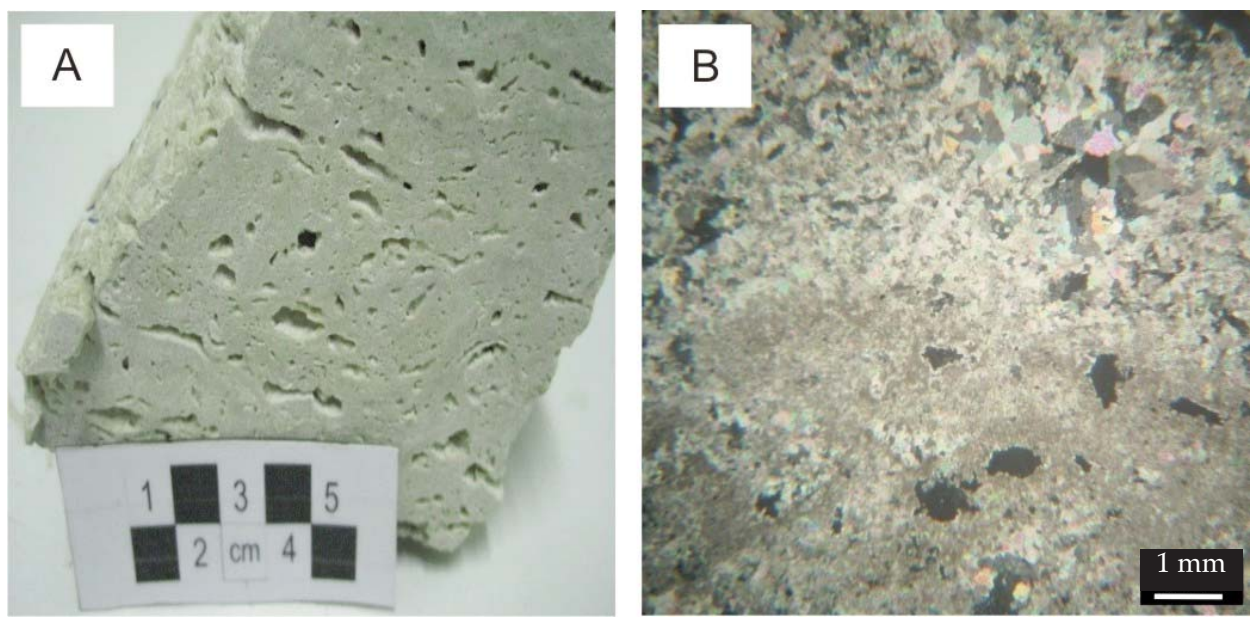

Fig. 4

Pictures of second type travertine. (A, B) Hand specimen and microscopic section (crossed polars) showing significant amounts of mouldic, shelter, and vuggy porosity

and shape of calcite, porosity, and/or permeability of the Ab Ask travertine must be related to diagenesis, as described by James and Choquette (1984) for carbonates. On the basis of XRD analysis this travertine is mainly composed of calcite with a minor amount of quartz (Table 2). On the basis of its morphology and lithofacies, these travertine types are classified under the names of fissureridge, dam and cascade.

2-1.) Fissure-ridge travertine occurs as calcium carbonate saturation waters rise through fractures or faults, causing travertine deposition on both sides of fissures (e.g. Hancock et al. 1999). Three instances of inactive fissure-ridge travertine are exposed in the studied area of N20-30W trend (Fig. 5A). This travertine was probably formed in relation to the extensional settings similar to that of the Cambazli village area in Turkey reported by Selim and Yanik (2009). There is a fissure at the center of the travertine ridge and parallel to this fissure, laminated, hard and compact crystalline crusts are present, which can be called vertically banded travertine (Altunel 1994). The fissure-ridge travertine in the Ab Ask area is comparable with the Cukurbag fissure-ridge located close to the Pamukkale travertine deposit of western Turkey (Hancock et al. 1999).

Model studies and current observations suggest that high pressure $\mathrm{CO}_{2}$ coming from mantle degassing and/or decarbonation of crustal carbonate rocks may accumulate in crustal traps in tectonically active regimes and induce seismicity (Chiodini et al. 2004). Faults and fractures in such an active area can provide channels for $\mathrm{CO}_{2}$-rich hydrothermal fluids to ascend to the surface. Veins 

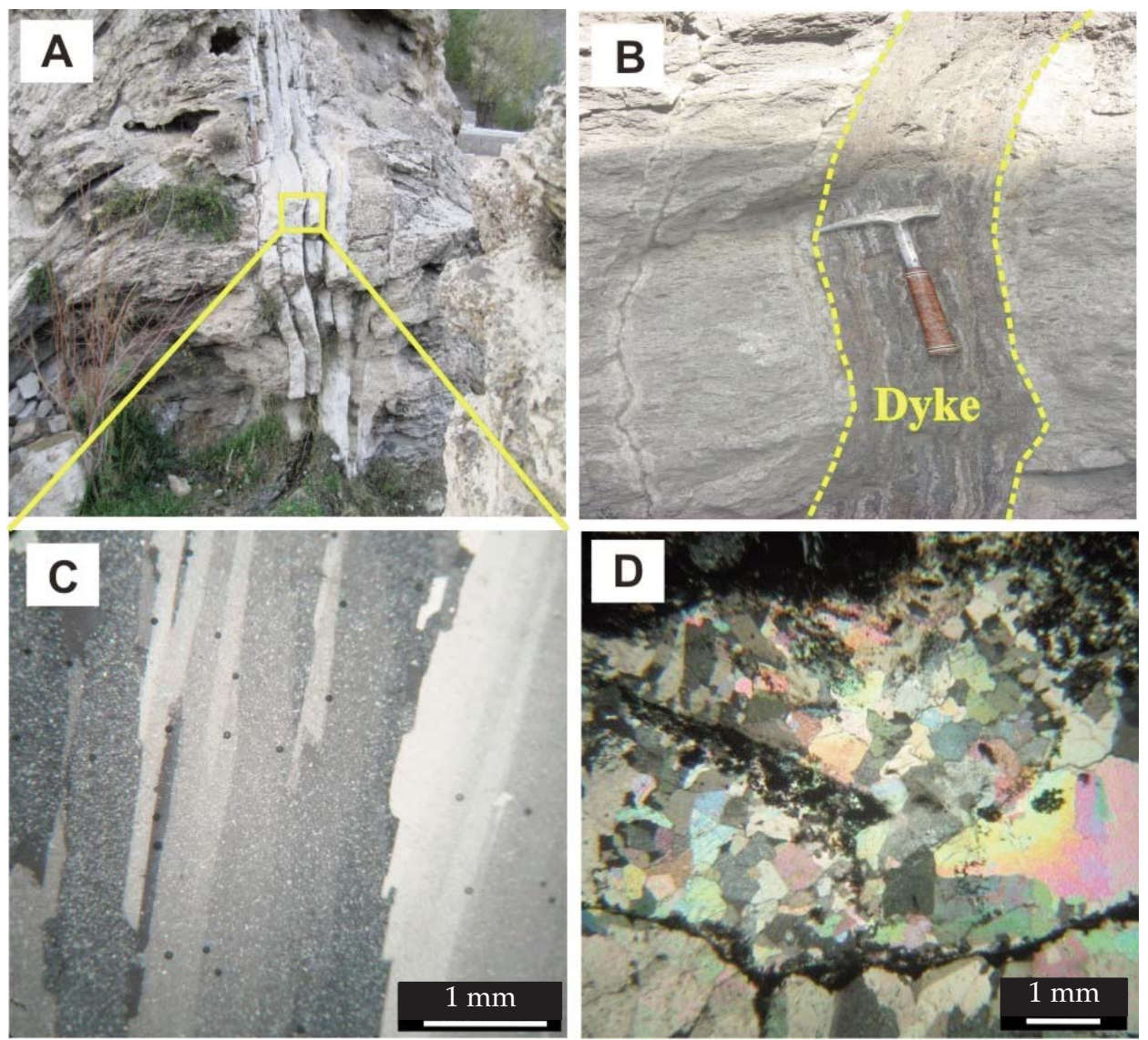

Fig. 5

Pictures of veins. (A) Calcite veins filling the fissures inside the ridges in the region. (B) Veins propagating toward the surface as dyke structures within the earlier deposited bedded travertine. (C) Photomicrograph of fissure-ridge vein travertine showing elongate blocky texture of large calcite crystals, (crossed polars). (D) Photomicrograph of veins showing that they are composed of calcite, pyrite, gypsum and rancieite? (crossed polars)

are interpreted to be hydrothermal eruption products (Browne and Lawless 2001), which probably formed by hydraulic fracturing in response to internal overpressure of $\mathrm{CO}_{2}$-rich fluids. The overpressure resulting from positive buoyancy of such fluids is the driving force for the propagation of hydrofractures to the surface (Uysal et al. 2009). Calcite veins occur within the pre-existing horizontally-bedded travertine and which also fills the fissures inside the ridges in the region (Fig. 5A, B). Mineralogical and textural studies show that some of these veins mainly contain calcite with an elongate blocky texture (Fig. 5C); some others are composed of calcite, pyrite, gypsum and a rather rare mineral which 
can be rancieite (Fig. 5D, Table 2). Similar veins to those in the Ab Ask area were reported by Uysal et al. (2009) in the fissure-ridge travertine at Pamukkale.

Microscope and SEM observations show that biological activity such as cyanobacteria (Fig. 6B) and diatoms (Fig. 6C) may have had some role in fissureridge travertine deposition (Fig. 6A). The small amount of silica phase, namely quartz, observed in XRD spectra, are probably the remnants of those diatom shelves which were living in such restricted hot and calcareous waters. These biological organisms could lead to carbon dioxide reduction in the environment, causing carbonate supersaturation and finally travertine sedimentation by photosynthetic activities. They have locally influenced the travertine microfabric by providing sites for the trapping and nucleation of calcite at the cell surface (Pentecost et al. 1997).

2-2.) Dam travertine is inactive and formed around the Yeyllagh Spring (Fig. 6D). This type of travertine can be distinguished from cascades by its localized vertical accretion leading to water impoundment as pools, ponds and lakes (Pentecost 2005). A large amount of plant fragments can accumulate here by water flow and later on be bound together by growing algae and coated by lime building up the dams. Well-known examples of dam travertine are the Huanglong Ravine, Sichuan, China (Pentecost 2005).

2-3.) Cascade (waterfall) travertine can form steep slopes as a result of the elevated degassing caused by the strong turbulence of water (Figs 6E, F, and G). Some occurrences are active at present (Fig. 6F). They have an approximately paraboloid cross-section and are frequently accompanied by the fluted channels that have been interpreted as erosively-shaped deposits by Pentecost (2005), in which the morphology has largely been controlled by spate water trajectory. They have, however, formed as vertical falls along resistant rock layers (Dennen et al. 1990). Based on microscope studies this travertine is composed of columnar spar calcite (Fig. $6 \mathrm{H}$ ). Columnar spars are composed of crystallites with a width of $30-50 \mu \mathrm{m}$ and terminate in flat apices. They are also common in epigene travertine where they may be primary or the result of diagenesis (Chafetz et al. 1994). Examples include Sitting Bull Falls, New Mexico; Turners and Prices Falls, Oklahoma; the upper falls at Urach, Germany; Terni Falls, Italy, and the Huangguosho and Gaotang Falls, China (Pentecost 2005). In the UK good examples occur at Gordale and Waterfall Beck, Yorkshire (Pentecost 2005).

3.) Third type travertine (laminated travertine): This travertine type is mainly brown to yellow-brown (Fig. 7A) and is overlain by several horizons of paleosol, ash falls and quaternary alluvia (Fig. 7B) and therefore can be considered to be older than the other travertine in the area. The yellowish color of this travertine is related to its $\mathrm{Fe}_{2} \mathrm{O}_{3}$ content, which shows that it was precipitated from waters with high iron content, most probably coming directly from volcanic fumaroles and mixing with the waters, or coming from hematite-rich ash existing in the area. Laminated travertine is being exploited as ornamental stone. This lamination consists of alternating thin, dark, iron-bearing layers and thick, light, 

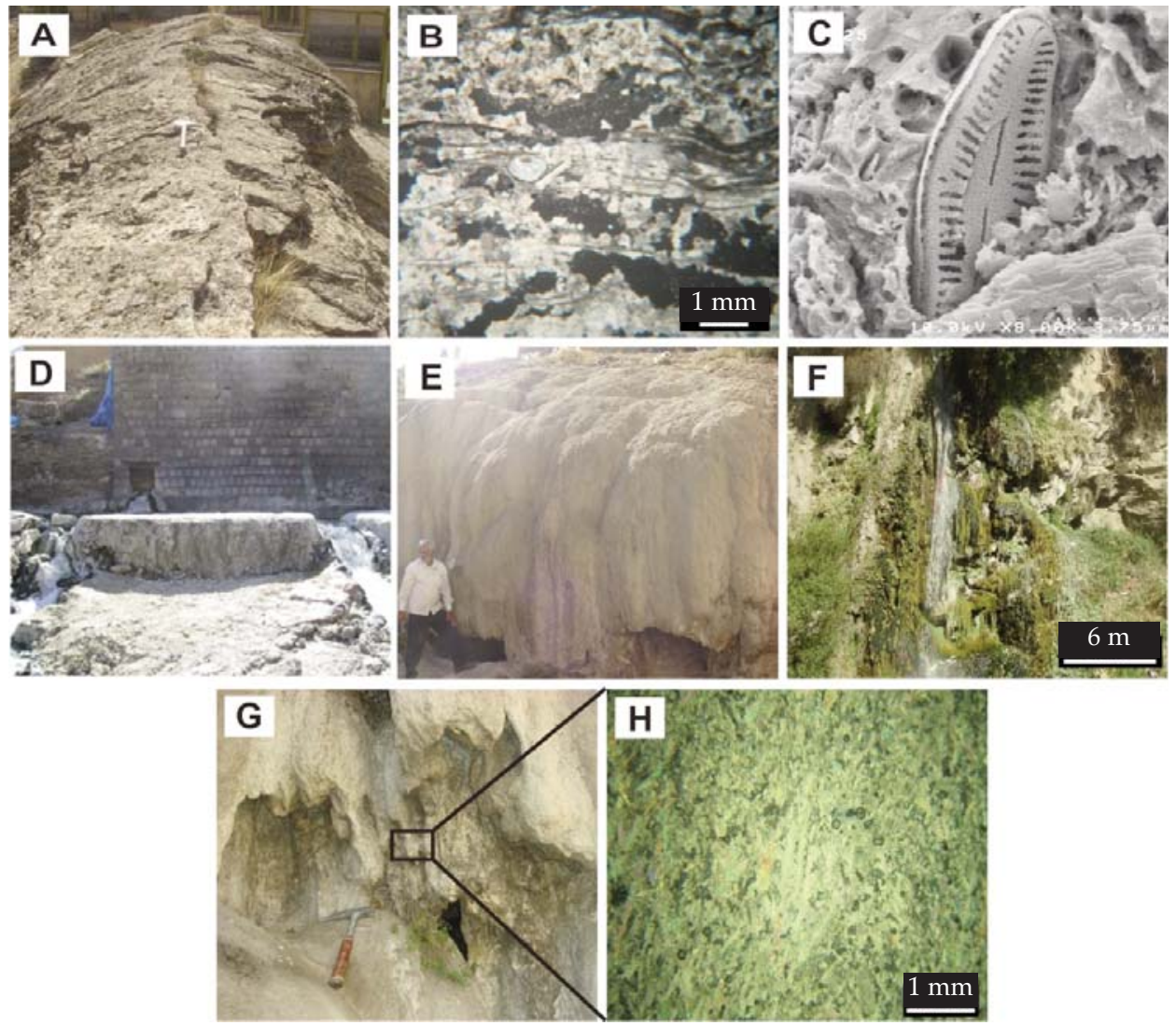

Fig. 6

Pictures of second type travertine morphologies. (A) Inactive fissure-ridge travertine. (B) Fragments of algal filaments in fissure-ridge travertine (crossed polars). (C) SEM images of fissure-ridge travertine taken from the SR A60 sample, with lenticular diatom frustules. (D) Dam travertine around the Yeyllagh Spring. (E) Inactive cascades (erosively shaped deposit types). (F) Active cascade (erosively shaped deposit types), along with overhanging bryophyte (moss) curtains and pouring water column. $(\mathrm{G}, \mathrm{H})$ Columnar spar crystallites in inactive cascade (crossed polars)

sparitic layers, which were probably formed by interruptions in water flow (Pentecost 1999) (Fig. 7C). Lamination between iron-bearing and iron hydroxide layers of calcite could readily be explained by changes in $\mathrm{pH}$ within the waters from which the laminated travertine precipitated. Changes in $\mathrm{pH}$ at a site could be the result of: (1) changes in the composition of the waters issuing from the spring, (2) differences in the volume of water such that degassing of $\mathrm{CO}_{2}$ (which results in $\mathrm{pH}$ changes) takes place closer to, or farther from, the spring, or (3) changes in the location, and thus distance, of the spring from the site of precipitation (Chafetz and Lawrence 1994). As a result, it can be concluded that, as $\mathrm{pH}$ increased downstream from the springs in the Ab Ask area, deposition of 

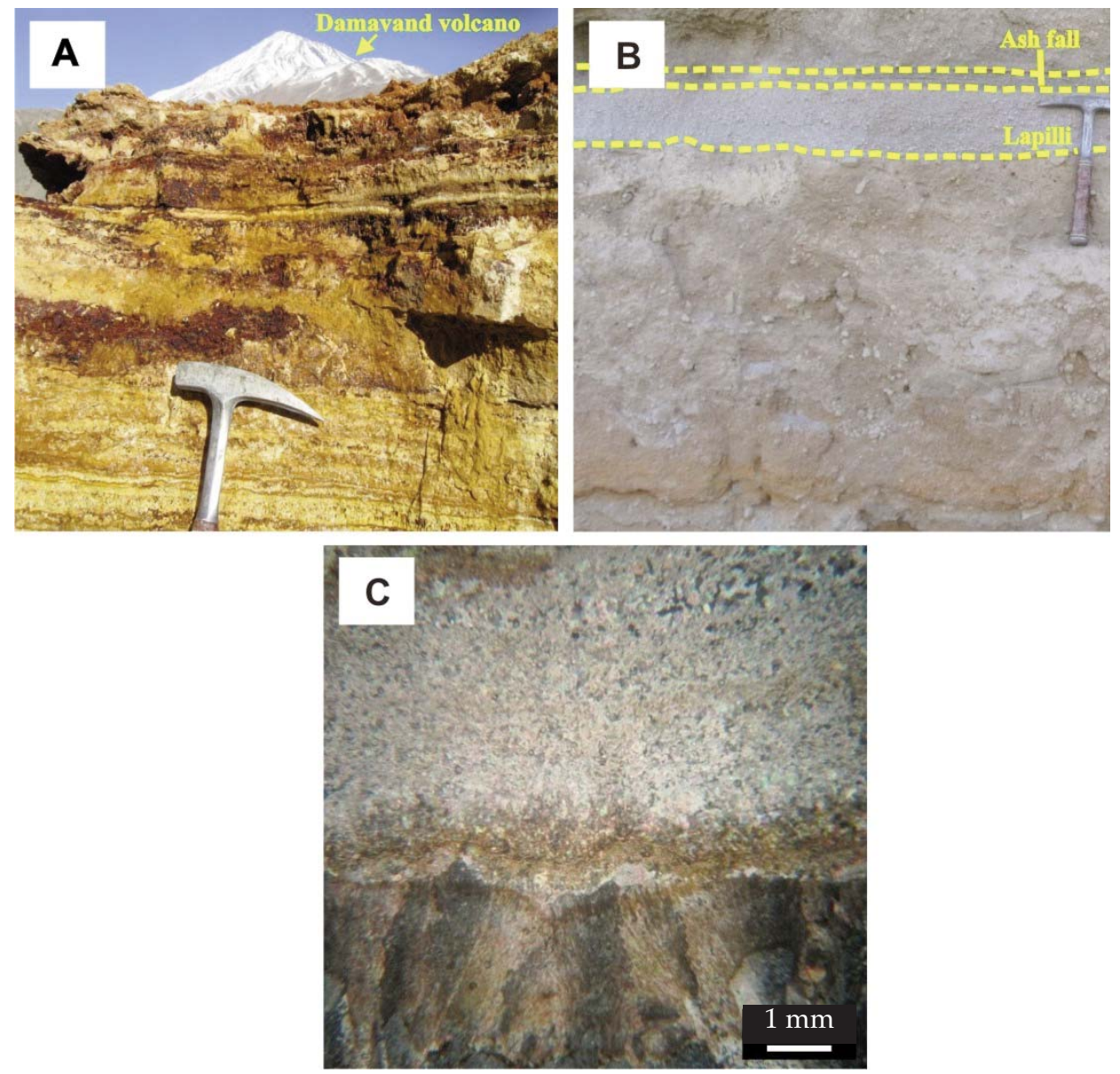

Fig. 7 .

Photograph of brownish-yellowish laminated travertine. (A) Laminated travertine crusts showing alternating light and dark laminae. (B) Horizons of paleosol, ash falls and Quaternary alluvia at the top of laminated travertine. (C) Thin section of microphotograph of the laminated travertine (crossed polars)

Fe-oxides and carbonates must have been sequentially favored, similarly to the successive precipitation of those minerals in southern Morocco reported by Chafetz et al. (1998).

On the other hand, laminations in travertine could also form by daily or seasonal cycle in cyanobacterial metabolism (Chafetz et al. 1998). Folk et al. (1985) and Guo and Riding (1992) reported laminae from Italian travertine and attributed their origin to changes in the activity of photosynthetic bacteria due to diurnal variations in the intensity of sunlight and probably temperature. The 
mineralogical composition of yellow travertine is $95 \% \mathrm{CaCO}_{3}$ and about $5 \%$ quartz and iron oxide impurities (limonite and hematite) according to X-ray diffraction analyses (Table 2). Four major types of cement were recognized in $\mathrm{Ab}$ Ask laminated travertine: isopachous cement, bladed cement, drusy cement and blocky calcite cement (Fig. 8).

1.) The isopachous cement is composed of rhombohedral crystals growing perpendicular to the pore walls, and is the first cement to indicate that precipitation proceeded under phreatic conditions (Fig. 8A).

2.) The bladed spar crystal comprises weakly radiating tooth-like crystals in vertical section, and is one of the most common crystal morphologies in the laminated travertine (Fig. 8A). When these crystals are present as parallel arrays they can be described as palisades. Palisades of calcite alternating with layers of micrite are considered as clear evidence of growth interruption in laminated travertine (Fig. 8B). The presence of bladed calcite crystals in the laminated samples supports a subaqueous precipitation environment.

3.) Drusy cement is characterized by crystal size increasing from pore walls to the center of the pore spaces and could be considered as secondary cement (Fig. $8 \mathrm{C}, \mathrm{D})$. It is composed of unhedral to subhedral crystals, pore-filling but with no preferred orientation.
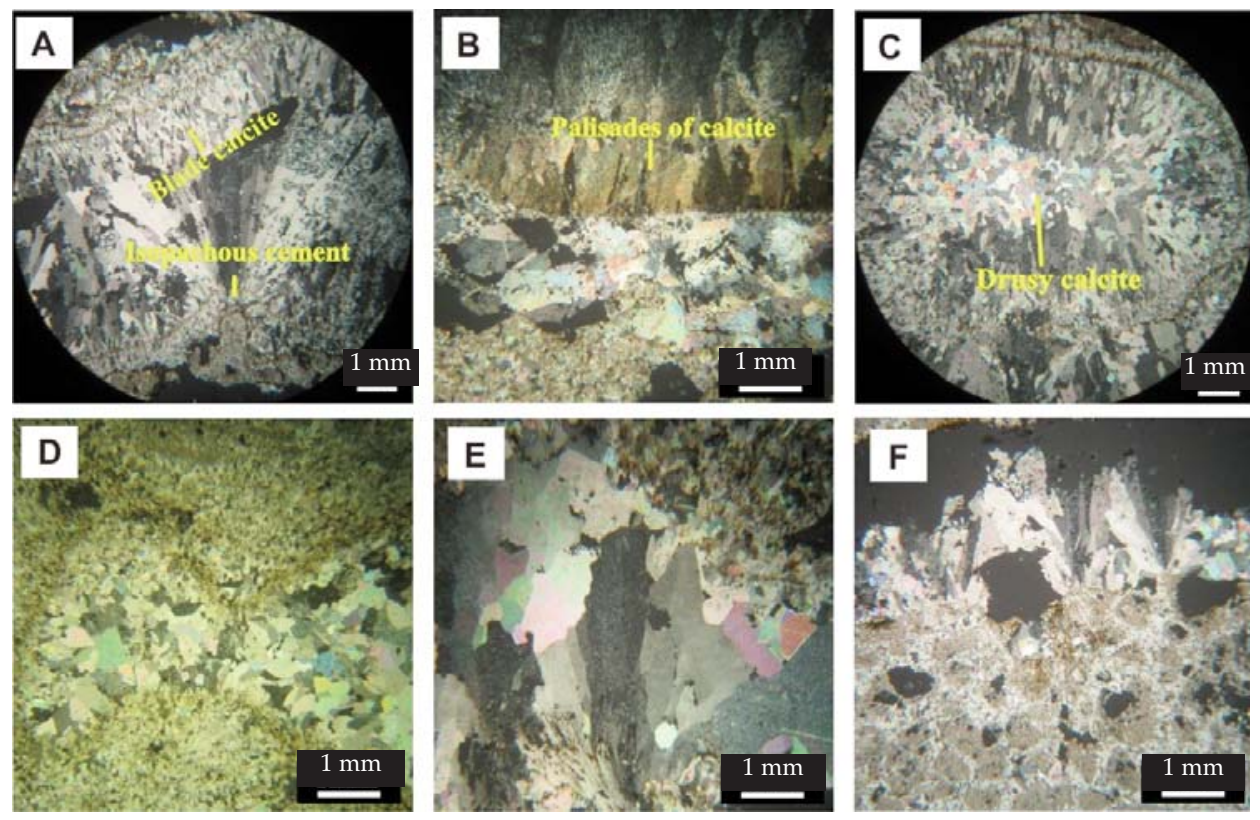

Fig. 8

Thin-section photomicrographs of laminated travertine (A) Blade calcite crystals and isopachous cement, (crossed polars), (B) Columnar-bladed calcite crystals (palisades of calcite), (crossed polars), (C, D) Drusy calcite cement (crossed polars), (E) Blocky calcite cement (crossed polars), (F) Densely clustered brown peloid aggregates (crossed polars) 
4.) Blocky calcite cement is an index of phreatic burial environments (Fig. 8E). The latter cement is clearer and larger than meteoric phreatic cements.

Cement propagation is the most important diagenetic process which reduces porosity and permeability in travertine. Peloids which are observed in thin sections of laminated travertine could interpreted as a non-skeletal component of the travertine in the region. They have a spherical to ellipsoid shape, are about 300-600 $\mu \mathrm{m}$ long, with lack a of internal structure and brownish color, occurring in loosely or densely clustered aggregates (Fig. 8F). These clumps of peloids occur in a wide range of travertine and are probably microbial in origin (Pentecost 2005), or their formation might be related to algal activities (Flügel 2004).

\section{Stable isotope measurements}

Stable carbon and oxygen isotope compositions of travertine can provide insight into the origin (sources) of carbon and the precipitation conditions (Friedman 1970). We used the carbon isotope compositions to determine the source of the $\mathrm{CO}_{2}$ which was dissolved in the parent waters of the travertine. Stable carbon and oxygen isotope compositions were determined for 16 samples of travertine, veins and cement. The $\delta^{13} \mathrm{C}$ and $\delta^{18} \mathrm{O}$ isotope values (Table 3) show broad variations. Stable isotope compositions demonstrate enrichment of the travertine in ${ }^{13} \mathrm{C}$ (6 to $9.8 \%$ VPDB) and in ${ }^{18} \mathrm{O}$ values (-13.0 to $-6.3 \%$ VPDB) downstream from the hot springs, whereas $\delta^{13} \mathrm{C}$ and $\delta^{18} \mathrm{O}$ values of veins vary between $5.8 \%$ o to $5.95 \%$ and $-14.38 \%$ o to $-11.68 \%$, respectively.

\section{Discussion}

The source of $\mathrm{CO}_{2}$ and isotopic variations in travertine and veins.

The carbon dioxide can originate from a wide range of sources, including hydrolysis and oxidation of reduced carbon, thermometamorphic decarbonation of limestone or directly from degassing of the upper mantle, mainly in areas of volcanic activity (Pentecost and Viles 1994). One frequently applied method for the determination of the origin of $\mathrm{CO}_{2}$ is the formula:

$$
\delta^{13} \mathrm{C}_{\left(\mathrm{CO}_{2}\right)}=1.2 \delta^{13} \mathrm{C}_{(\text {travertine) }}-10.5
$$

This equation, which was originally proposed on the basis of a survey of Italian thermal springs and associated travertine by Panichi and Tongiorgi (1976), can be used to recalculate the original ${ }^{13} \mathrm{C} /{ }^{12} \mathrm{C}$ ratios of $\mathrm{CO}_{2}$ from the measured $\delta^{13} \mathrm{C}$ values of fossil travertine. Using the measured $\delta^{13} \mathrm{C}$ values of travertine this formula gives the $\delta^{13} \mathrm{C}$ of the $\mathrm{CO}_{2}$ released from the water during travertine deposition (Kele et al. 2003; Minissale 2004). As shown in Fig. 9, the carbon isotopic compositions of $\mathrm{CO}_{2}$ and travertine at the travertine-depositing springs are expressed by this equation. 


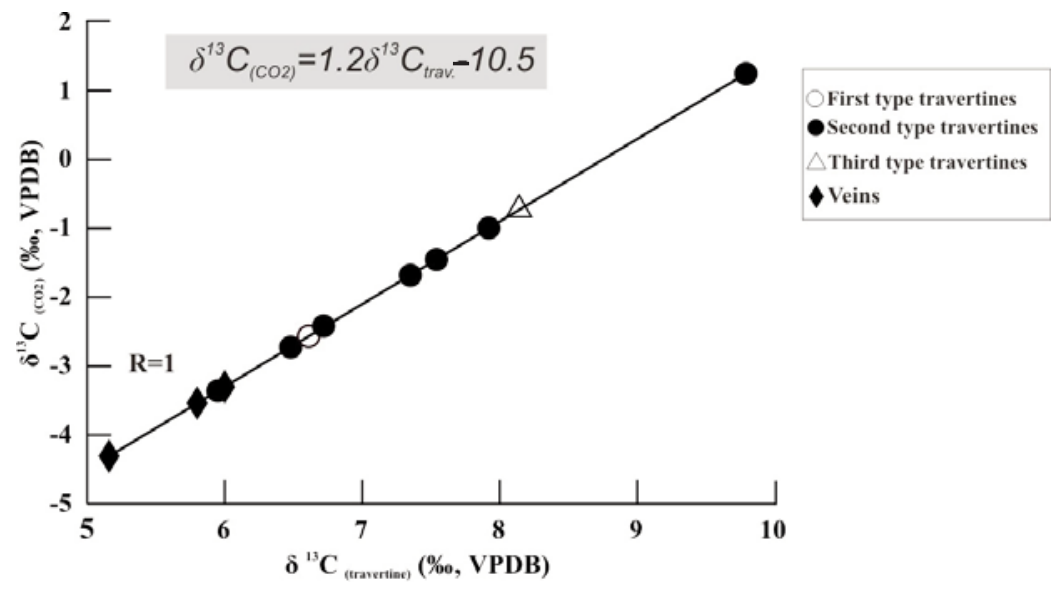

Fig. 9

$\delta^{13} \mathrm{C}$ of $\mathrm{CO}_{2}$ vs. $\delta^{13} \mathrm{C}$ in travertine. $\delta^{13} \mathrm{C}$ values of $\mathrm{CO}_{2}$ recalculated from $\delta^{13} \mathrm{C}$ values of travertine according to the formula of Panichi and Tongiorgi (1976) shown at the top of the diagram

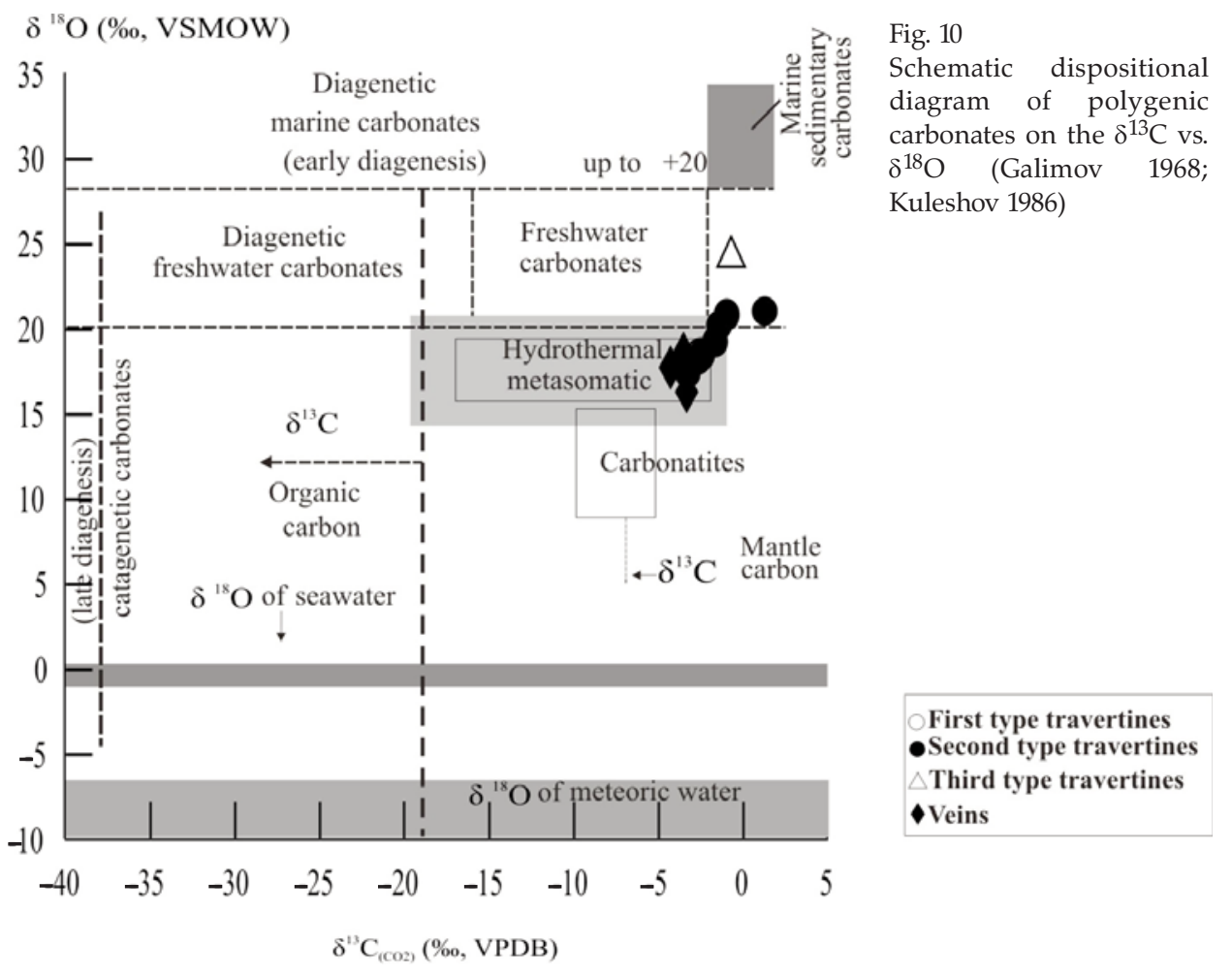


Using (eq. 1) the $\delta^{13} \mathrm{C}$ of the original $\mathrm{CO}_{2}$ of the travertine and veins is about -3.3 to $1.25 \%$ and -4.3 to ?3.36\% , respectively (Table 3 ).

The $\delta^{13} \mathrm{C}\left(\mathrm{CO}_{2}\right)$ and $\delta^{18} \mathrm{O}$ values show that travertine and veins were probably deposited from hydrothermal metasomatic fluids (Fig. 10). Most hydrothermal karst systems owe their existence to the role of carbon dioxide, whose origin, in contrast to normal karst, is not the soil zone but deep-seated $\mathrm{CO}_{2}$ sources, such as decarbonation reactions during rock metamorphism (Spötl et al. 2009).

Considering that the $\mathrm{CO}_{2}$ content originating from magmatic sources generally has very low $\delta^{13} \mathrm{C}$ values (from -8 to -4 VPDB; Craig 1963), it could be concluded that some of the veins in the area have had a magmatic source (Table 3). Applying the formula of Panichi and Tongiorgi (1976) the recalculated $\delta^{13} \mathrm{C}$ values for travertine and some veins are more positive than the $\delta^{13} \mathrm{C}$ value of $\mathrm{CO}_{2}$ coming from a pure igneous source, obviously due to the additional heavy carbon. According to Shieh and Taylor (1969) heavy $\mathrm{CO}_{2}$ can be produced through metamorphic reactions (i.e. decarbonation of carbonate rocks).

According to Fig. 11 travertine is in the range of hydrolysis of carbonate rocks, while veins are located at the boundary between the magmatic and carbonate hydrolysis domains.

The plot of $\delta^{18} \mathrm{O}$ versus $\delta^{13} \mathrm{C}$ shows a linear covariation trend between $\delta^{18} \mathrm{O}$ and $\delta^{13} \mathrm{C}$ (Fig. 12) with a high correlation coefficient $(\mathrm{R}=0.687)$. Thus, as in case of Mammoth hot spring travertine (Guidry and Chafetz 2002), the observed linear trend in $\mathrm{Ab}$ Ask travertine could represent:

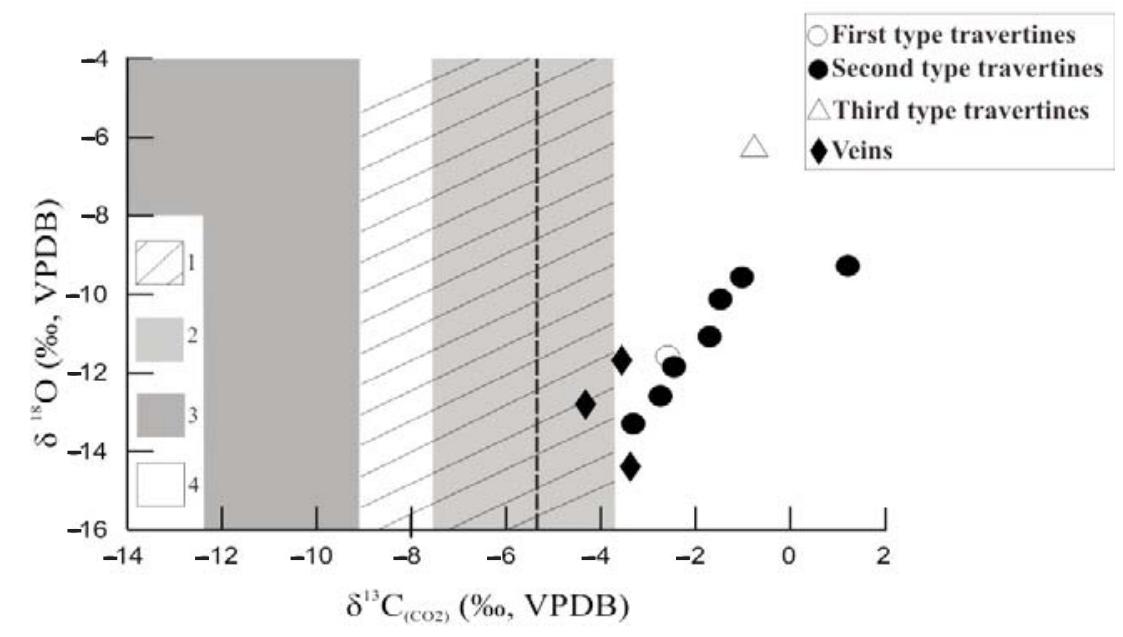

Fig. 11

$\delta^{18} \mathrm{O}$ vs. calculated $\delta^{13} \mathrm{C}$ content of primary $\mathrm{CO}_{2}$ in travertine and its genesis (Milivojevic 1989) (1. Endogenic-magmatic $\mathrm{CO}_{2}$ (Fournier 1981); 2. Endogenic-magmatic $\mathrm{CO}_{2}$ (Blavoux et al. 1982); 3. organic and sedimentary $\mathrm{CO}_{2} ; 4 . \mathrm{CO}_{2}$ produced by geothermally decomposed and hydrolyzed carbonate rocks) 


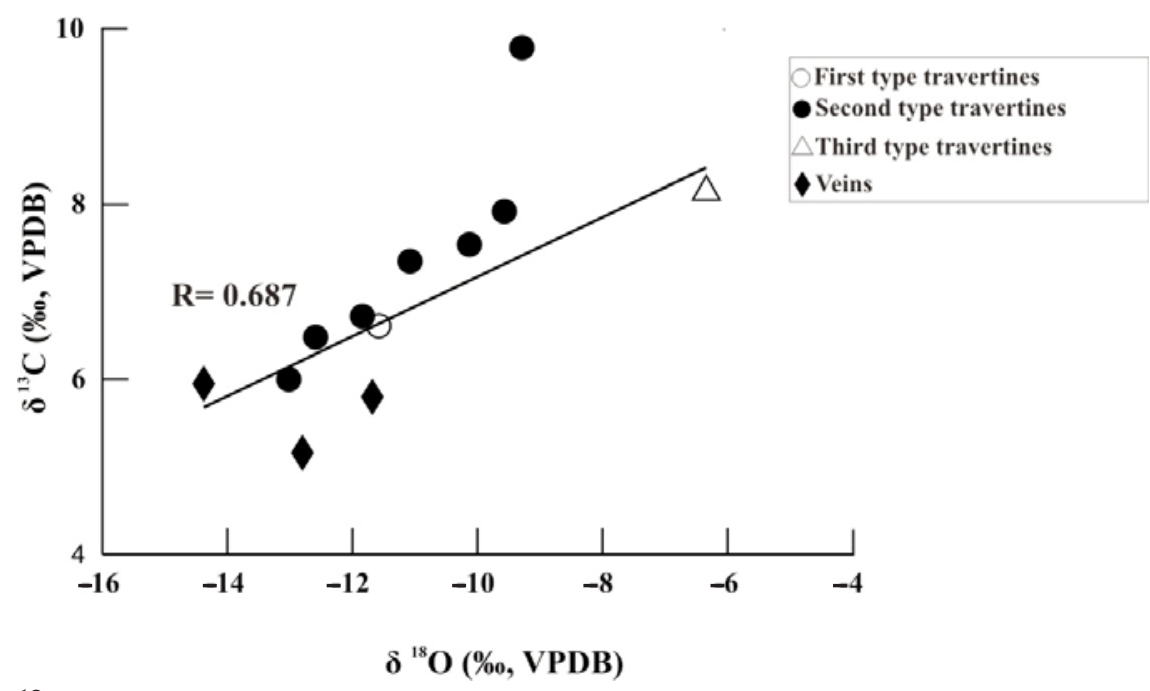

Fig. 12

Bivariate plot of oxygen and carbon isotope composition of Ab Ask travertine. Correlation between the $\delta^{18} \mathrm{O}$ and $\delta^{13} \mathrm{C}$ values indicates that they are positively correlated and define a trend resembling a mixing line

1.) variable mixing of waters that interacted with Paleozoic limestone aquifers, and other hydrothermal waters, as well as surface meteoric waters,

2.) long-term change in the temperature of the hot spring system, e.g. progressive heating of the system,

3.) diagenetic alteration, and

4.) a combination of all these factors.

Also, partial $\mathrm{CO}_{2}$ and $\mathrm{H}_{2} \mathrm{O}$ removal during progressive degassing of $\mathrm{CO}_{2}$ and evaporation could cause a positive shift in $\delta^{13} \mathrm{C}$ and $\delta^{18} \mathrm{O}$ values. Low oxygen isotope values show that this travertine was deposited from high-temperature fluids. The third type travertine (laminated travertine) has enriched $\delta^{18} \mathrm{O}$ values $(-6.34 \% o)$, which may be attributed in part to the evaporation and temperature decrease with increasing distance from the springs during precipitation.

\section{The effect of diagenesis on the $\delta^{18} \mathrm{O}$ and $\delta^{13} \mathrm{C}$ values}

Meteoric diagenesis mainly affects oxygen isotope values, whereas diagenesis may influence both the $\delta^{18} \mathrm{O}$ and $\delta^{13} \mathrm{C}$ values of travertine due to the influx of external, C-bearing fluids during recrystallization. However, the $\delta^{18} \mathrm{O}$ and $\delta^{13} \mathrm{C}$ values of secondary calcite in second type travertine (sample SR M14) are about $-12.88 \%$ and $5.97 \%$, respectively, and in third type travertine (sample SR A32) of about $-6.73 \%$ and $7.96 \%$, respectively, and thus very similar to their host travertine (Table 3). Because the carbon from travertine is transmitted to 
secondary calcite with slight changes, in the case of closed systems without any additional organic carbon, the influence of diagenesis on the carbon isotope should be very low, as is observed in the present study. It could, therefore, be concluded that meteoric diagenesis, namely cementation, does not considerably affect, in such a system of pore waters of meteoric origin, the carbon isotopic composition of either the travertine or those of the cement.

Considering the observed linear trend between $\delta^{13} \mathrm{C}$ and $\delta^{18} \mathrm{O}$ values in the $\mathrm{Ab}$ Ask travertine (Fig. 12), it is likely that the fluids responsible for the formation of this travertine and these veins are mixtures of fluids (for example meteoric and hydrothermal waters) of different origins. Carbonate formations have undergone a continuous decarbonation process as a result of the reaction of $\mathrm{CO}_{2}$-rich hydrothermal fluids with these rocks. These fluids contained $\mathrm{CO}_{2}$ gas released through hydrolysis of the carbonate rocks and carried to the surface with the emerging thermal springs, precipitating travertine due to rapid degassing of $\mathrm{CO}_{2}$, partly due to biological activities. The drop in the partial pressure, while raising the fluids to the surface, leads to a decrease in the solubility of $\mathrm{CO}_{2}$ in water and, ultimately, veins are precipitated in the fracture zones due to rapid $\mathrm{CO}_{2}$ degassing.

\section{Effective factors controlling the $\delta^{13} \mathrm{C}$ values}

As was observed, all types of travertine and veins have relatively high $\delta^{13} \mathrm{C}$ values. According to Kele et al. (2011) high $\delta^{13} \mathrm{C}$ values of Pamukkale travertine has been attributed to two different sources:

1.) contribution of $\mathrm{CO}_{2}$ liberated by thermometamorphic decarbonation of carbonate rocks and

2.) magmatic $\mathrm{CO}_{2}$ which was revealed through $\mathrm{He}$ isotopic studies of Gülec et al. (2002).

High $\delta^{13} \mathrm{C}$ values (between 6 and 9.79\%o) of Ab Ask travertine could also be attributed to the contribution of heavy $\mathrm{CO}_{2}$ (rich in ${ }^{13} \mathrm{C}$ ) liberated during thermometamorphic decarbonation of carbonate basement rocks (most probably Mesozoic limestone). High-temperature thermometamorphic processes are usually related to the areas of elevated geothermal activity, such as travertine in Fiano Romano with $\delta^{13} \mathrm{C}$ values between 6 and 9\%o VPDB, and Yellowstone thermal springs with $\delta^{13} \mathrm{C}$ values between 3 and 8\%o VPDB (Craig 1963) which are related to the carbonate rocks existing in the substrate. During rapid degassing of $\mathrm{CO}_{2}$ from thermal waters, non-equilibrium isotope fractionation can occur and as a result, heavy carbon isotope becomes concentrated in the precipitated travertine (Pentecost 2005). The isotopic composition of carbonates precipitating from water is also affected by the activity of blue-green algae, which are widespread on the surface of travertine. The photosynthesis process results in the 
preferable consumption of $\mathrm{CO}_{2}$ with the light carbon isotope by plants (Guo et al. 1996).

Based on the origin of the $\mathrm{CO}_{2}$ interacting with the groundwater, Pentecost (2005) subdivided travertine into meteogene and thermogene or thermal deposits. Meteogene travertine (i.e. calcareous tufa) generally shows a negative carbon isotopic composition $\left(\delta^{13} \mathrm{C}\right.$ vs. VPDB between -11 to $0 \%$ ) reflecting the depleted $\delta^{13} \mathrm{C}$ of soil $\mathrm{CO}_{2}$ (Deines 1980). Thermogene travertine, on the other hand, values of $\delta^{13} \mathrm{C}$ vs. VPDB in the range -1 to $10 \%$ (D'Alessandro et al. 2007). According to geologic observations and isotopic analysis obtained for the present study, the Ab Ask travertine can be regarded as thermogene travertine and is comparable with the Viterbo and Rapolano Terme travertine in Italy (Fig. 13). Waters responsible for these deposits are normally hot and carry $\mathrm{CO}_{2}$ coming from the interaction between hot rock and $\mathrm{CO}_{2}$-rich fluids (Ohmoto and Rye 1979).

\section{Conclusions}

Travertine deposits in the Ab Ask area were studied using combined petrographic, mineralogical and stable isotope analysis. Based on their sedimentation sequence and lithofacies, travertine is categorized into three main types of first (stream channel deposits), second and third type (laminated) travertine. First type travertine consists of fresh and recent carbonate sediments in the streams and channels from hot water. Second type travertine consists of white to cream-colored, massive deposits which, based on their morphology and lithofacies, are classified into four kinds as fissure-ridge, dam, cascade, and blocky types. Third type travertine consists of laminated travertine, having undergone high to moderate diagenesis, of yellow to brown color. XRD analysis showed that the travertine is composed of almost pure calcite with minor amounts of quartz, whereas veins contain some amounts of pyrite, gypsum and rancieite in addition to calcite. Diagenetic features in second and third types of travertine (laminated travertine) led to distinguishing two burial and meteoric diagenesis environments. Based on carbon and oxygen isotopic analysis of travertine a linear trend was observed between $\delta^{13} \mathrm{C}$ and $\delta^{18} \mathrm{O}$ values with increasing distance from hot springs, which is attributed to the mixing of two or more different fluids.

Fig. $13 \rightarrow$

Comparison of travertine geochemistry in Ab Ask with different travertine locations from around the world

$\mathrm{Ab}$ Ask (present study); (Angel Terrace, Yellowstone), (Bagnaccio, Viterbo, ltaly), (Bridgeport California), (Rapolano Terme, ltaly), (New Highland Terrace, Yellowstone), (Narrow Gauge, Yellowstone), (Pagosa Springs, Colorado), and Budakalász (Buda Mts, Hungary, Pleistocene travertine) (Kele et al. 2003); Gerecse Mts and Eger (Szöőr et al. 1992); Süttő (Sierralta et al. 2010); SW flank of Mt. Etna (Italy) (D'Alessandro et al. 2007); Southern Tibet (Zentmyer et al. 2008); Buda Castle Hill (Korpás et al. 2004); Pamukkale (Kele et al. 2011); Tata and Kôpite Hill (Kele et al. 2006); travertine cone (SVértes Mts.) (Siklósy et al. 2006); Egerszalók (Kele et al. 2008) 


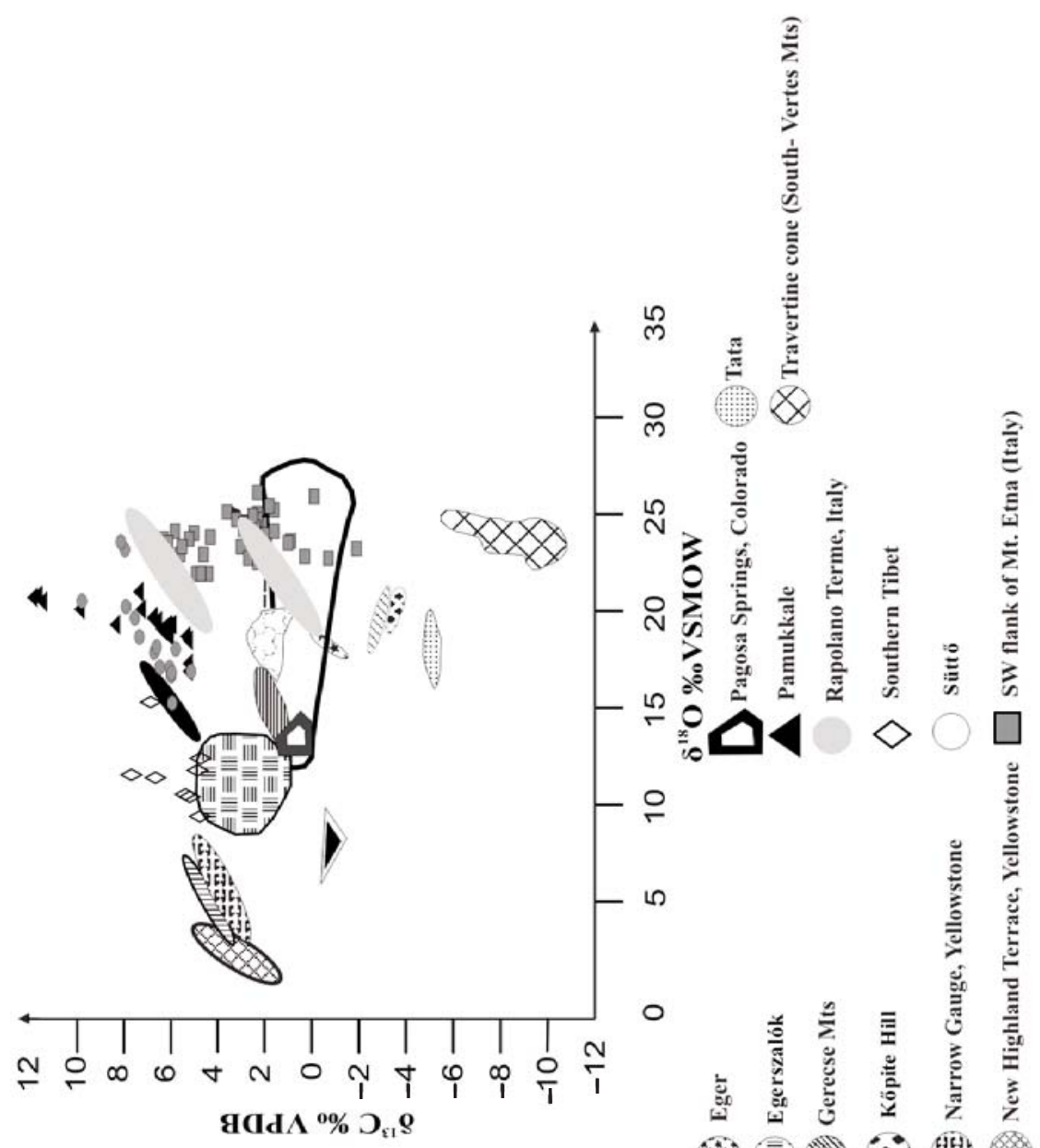

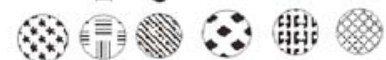

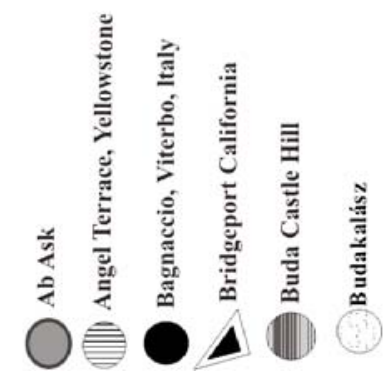

Central European Geology 55, 2012 
There is a significant enrichment in $\delta^{13} \mathrm{C}$ values of all travertine types due to decarbonation of limestone, algae activity and rapid degassing. Isotopic studies reveal that the travertine of the Ab Ask area may be of thermal water origin and therefore belong to the thermogene travertine category.

\section{Acknowledgements}

The authors thank the Research Council at the University of Tehran for supporting the present study. We are grateful to Dr Sándor Kele and Dr Enrico Capezzuoli for their constructive and fruitful comments to improve the paper.

\section{References}

Alavi, M. 1996: Tectonostratigraphic synthesis and structural style of the Alborz Mountain system in Northern Iran. - Geodynamics, 21, pp. 1-33.

Allen, M., M.R. Ghassemi, M. Shahrabi, M. Qorashi 2003: Accommodation of late Cenozoic oblique shortening in the Alborz range, northern Iran. - Journal of Structural Geology, 25, pp. 659-672.

Allenbach, P. 1966: Geologie und Petrographie des Damavand und seiner Umgebung (Zentral Elburz), Iran. - Mitteilungen, Geologisches Institut, ETH und Universität Zürich, Neue Folge 63, pp. 1-144.

Allenbach, P., R. Shteiger 1966: Geologic map of Damavand 1:100000 survey sheet. - Geological Survey of Iran.

Altunel, E. 1994: Active tectonics and the evolution of Quaternary travertines at Pamukkale, Western Turkey. - Ph.D thesis, University of Bristol, $236 \mathrm{p}$.

Altunel, E., P.L. Hancock 1993a: Active fissuring and faulting in Quaternary travertines at Pamukkale, western Turkey. - In: Stewart, I.S., C. Vita-Finzi, L.A. Owen (Ed.): Neotectonics and Active Faulting Z. Geomorphology Supplement, 94, pp. 285-302.

Altunel, E., P.L. Hancock 1993b: Morphology and structural setting of Quaternary travertines at Pamukkale, Turkey. - Geological Journal, 28, pp. 335-346.

Altunel, E., P.L. Hancock 1994: Active fissuring and faulting in Quaternary travertines at Pamukkale, western Turkey. - Zeitschrift für Geomorphologie-Supplement band 94, pp. 285-302.

Ambraseys, N.N., C.P. Melville 1982: A history of Persian earthquakes. - Cambridge University Press, New York, 219 p.

Axen, G.J., D.F. Stockli, P. Lam, B. Guest, J. Hassanzadeh 2001: Implications of preliminary (U-Th/He cooling ages from the central Alborz Mountains, Iran. - Geological Society of America, Abstracts with Programs, 33, p. 257.

Berberian, M. 1983: The southern Caspian: A compressional depression floored by a trapped modified oceanic crust. - Canadian Journal of Earth Sciences, 20, pp. 163-183.

Blavoux, B., J. Dazy, J. Sarrot-Reynauld 1982: Information about the origin of thermomineral waters and gas by means of environmental isotopes in eastern Azerbaijan, Iran, and southeast France. - Journal of Hydrology, 56, pp. 23-38.

Breitenbach, S.F., S.M. Bernasconi 2011: Carbon and oxygen isotope analysis of small carbonate samples (20 to $100 \mu \mathrm{g}$ ) with a Gas Bench II preparation device. - Rapid Communications in Mass Spectrometry, 25, pp. 1910-1914.

Brogi A., E. Capezzuoli 2009: Travertine deposition and faulting: the fault-related travertine fissureridge at Terme S. Giovanni, Rapolano Terme (Italy). - International Journal of Earth Sciences, 98, pp. 931-947.

Browne, P.R.L., J.V. Lawless 2001: Characteristics of hydrothermal eruptions, with examples from New Zealand and elsewhere. - Earth-Science Reviews, 52, pp. 299-331. 
Casanova, J. 1986: Les stromatolites continentaux: paleoecologie, paleohydrologie, paleoclimatologie. - Application au rift Gregory, Thesis Sciences, Aix-Marseille-Ill, 256 p..

Chafetz, H.S., B. Akdim, R. Julia, A. Reid 1998: Mn- and Ferich black travertine shrubs: bacterially (and nanobacterially) induced precipitates. - Journal of Sedimentary Research, 68, pp. 404-412.

Chafetz, H.S., D. Srdoc, N. Horvantincic 1994: Early diagenesis of Plitvice Lakes waterfall and barrier travertine deposits. - Géogr. physique Quaternaire, 48, pp. 247-256.

Chafetz, H.S., J.R. Lawrence 1994: Stable isotopic variability within modern travertines. - Geographie Physique et Quaternaire, 48, pp. 257-273.

Chafetz, H.S., S.A. Guidry 2003: Deposition and diagenesis of Mammoth Hot springs travertine, Yellowstone National Park, Wyoming, U.S.A. - Canadian Journal Earth Sciences, 40, pp. 1515-1529.

Chiodini, G., C. Cardellini, A. Amato, E. Boschi, S. Caliro, F. Frondini, G. Ventura 2004: Carbon dioxide Earth degassing and seismogenesis in central and southern Italy. - Geophysical Research Letters, 31, L07615.

Craig, H. 1963: The isotopic geochemistry of water and carbon in geothermal areas. - In: Tongiorgi, E. (Ed.): Nuclear Geology in Geothermal Areas, Spoleto. Laboratorio di Geologia Nucleare, Pisa, pp. $17-53$.

D'Alessandro, W., S. Glammanco, S. Bellomo, F. Parello 2007: Geochemistry and mineralogy of travertine deposits of the SW flank of Mt. Etna (Italy): Relationships with past volcanic and degassing activity. - Journal of Volcanology and Geothermal Research, 165, pp. 64-70.

Deines, P. 1980: The isotopic composition of reduced carbon, pp. 329-407. - In P. Fritz, P., J.C. Fontes (Eds): Environmental Isotope Geochemistry. Elsevier, Amsterdam, 600 p.

Dennen, K.O., R.J. Diecchio, M.A. Stephenson 1990: The geology of the Falling Spring travertine deposit, Alleghany Co., Virginia. - In: Herman, J.S., D.A. Hubbard (Eds): Travertine-marl: Stream Deposits in Virginia. Virginia Division of Mineral Resources Publication 101, Charlottesville, Va (Virginia Division of Mineral Resources), pp. 79-92.

Fluegel, E. 1982: Microfacies analysis of limestones. Springer-Verlag, Berlin, 633 p..

Flügel, E. 2004: Microfacies of Carbonate Rocks: Analysis, Interpretation and Application, Springer Berlin, Heidelberg, New York, 976 p.

Folk, R.L., H.S. Chafetz, P.A. Tiezzi 1985: Bizarre forms of depositional calcite in hot-spring travertines, central Italy. - In: Schneidermann, N., P.M. Harris (Eds): Carbonate Cements. Special Publication Society of Economic Paleontologists and Mineralogists, 36, pp. 349-369. Tulsa.

Ford, T.D., H.M. Pedley 1996: A review of tufa and travertine deposits of the world. - Earth Science Reviews, 41, pp. 117-175.

Fouke, B.W., J.D. Farmer, D.J. Des Marais, L. Pratt, N.C. Sturchio, P.C. Burns, M.K. Discipulo 2000: Depositional facies and aqueous-solid geochemistry of travertine-depositing hot springs (Angel Terrace, Mammoth Hot Springs, Yellowstone National Park, U.S.A.). - Journal of Sedimentary Research, 70, pp. 565-585.

Fournier, R.O. 1981: Application of water geochemistry to geothermal exploration and reservoir engineering. - In: Rybach, L., L.J.P. Muffler (Eds): Geothermal Systems: Principles and Case Histories, ed. New York: Wiley, pp. 109-143.

Friedman, I. 1970: Some investigations of the deposition of travertine from hot-springs; the isotopic chemistry of a travertine-depositing spring. - Geochim. Cosmochim. Acta, 34, pp. 1303-1315.

Galimov, E.M. 1968: Geokhimiya stabil'nykh izotopov ugleroda (Geochemistry of Carbon Stable Isotopes), Moscow: Nedra.

Gruszczynski, M., B.J. Kowalski, R. Soltysik, H. Hercman 2004: Tectonic origin of the unique Holocene travertine from the Holy Cross Mts.: microbially and a biologically mediated calcium carbonate, and manganese oxide precipitation. - Acta Geologica Polonica, 54, pp. 61-76.

Guidry, S.A., H.S. Chafetz 2002: Petrography and stable isotopic trend associated with Mammoth Hot Spring travertine, Yellowstone National Park, Wyoming. - 33rd Lunar and Planetary Science Conference, Abstract 1149. 
Gülec, N., D.R. Hilton, H. Mutlu 2002: Heliumisotope variations in Turkey: relationship to tectonics, volcanism and recent seismic activities. - Chemical Geology, 187, pp. 129-142.

Guo, L., J. Andrews, R. Riding, P. Dennis, Q. Dresser 1996: Possible microbial effects on stable carbon isotopes in hot-spring travertines. - Journal of Sedimentary Research, 66, pp. 468-473.

Guo, L., R. Riding 1992: Aragonite laminae in hot water travertine crusts, Rapolano Terme, Italy. Sedimentology, 39, pp. 1067-1079.

Hancock, P.L., R.M.L. Chalmers, E. Altunel, Z. Cakir 1999: Travitonics: using travertines in active fault studies. - Journal of Structural Geology, 21, pp. 903-916.

Jackson, J., K. Priestley, M. Allen, M. Berberian 2002: Active tectonics of the South Caspian Basin. Geophysical Journal International, 148, pp. 214-245.

James, N.P., P.W. Choquette 1984: Diagenesis 9. Limestones. - The meteoric diagenetic environment. Geoscience Canada, 11, pp. 161-194.

Kele, S. 2009: Investigations on freshwater limestones from the Carpathian-Basin: palaeoclimatological and sedimentological studies. - PhD dissertation, ELTE, Budapest $176 \mathrm{p}$.

Kele, S., A. Demény, Z. Siklósy, T. Németh, M. Tóth, B. Kovács 2008: Chemical and stable isotope composition of recent hot-water travertines and associated thermal waters, from Egerszalók, Hungary: Depositional facies and non-equilibrium fractionation. - Sedimentary Geology, 211, pp. 53-72.

Kele, S., L. Korpás, A. Demény, P. Kovács-Pálffy, B. Bajnóczi, Zs. Medzihradszky 2006: Paleoenvironmental evaluation of the Tata Travertine Complex (Hungary), based on stable isotopic and petrographic studies. - Acta Geologica Hungarica, 49/1, pp. 1-31.

Kele, S., M. Özkul, I. Fórizs, A. Gökgöz, Oruç Baykara Mehmet, A.M. Cihat, T. Németh 2011: Stable isotope geochemical study of Pamukkale travertines: New evidences of low-temperature nonequilibrium calcite-water fractionation. - Sedimentary Geology, 238, pp. 191-212.

Kele, S., O. Vaselli, Cs. Szabó, A. Minissale 2003: Stable isotope geochemistry of Pleistocene travertine from Budakalász (Buda Mts, Hungary). - Acta Geologica Hungarica, 46/2, pp. 161-175.

Korpás, L., P. Kovács-Pálffy, M. Lantos, M. Földvári, L. Kordos, E. Krolopp, D. Stüben, Zs. Berner 2004: Sedimentology, geochemistry, chronology and palaeokarst evolution of Quaternary thermal lacustrine travertine. An integrated case study from Vár-hegy, Budapest, Hungary. - Bulletin of the Hungarian Geological Society 134/4, pp. 541-562.

Kuleshov, V.N. 1986: Izotopnyi sostav i proiskhozhdenie glubinnykh carbonatov (Isotopic Composition and Origin of Deep-Seated Carbonates), Moscow. - Nauka.

Martin, C. 1988: Composition chimique des eaux et travertins actuels dans le bassin superieur de I'Argens (Var), in: Les edifices travertineux et I'histoire de I'environnemenf. - Travaux de I'UA 903 du CNRS, 17, pp. 153-1 61.

Martinez-Diaz, J.J., J.L. Hernandez-Enrile 2001: Using travertine deformations to characterise paleoseismic activity along an active oblique-slip fault: the Alhama de Murcia fault (Betic Cordillera-Spain). - Geologica Acta, (antes Acta Geológica Hispánica), 36/3-4, pp. 297-313.

Milivojevic, M. 1989: Assessment of Geothermal Resources of Serbia Excluding Autonomous Provinces. - Doctoral thesis, Faculty of Mining and Geology, University of Belgrade, 459 p. (In Serbian.)

Minissale A., D.M. Kerrick, G. Magro, M.T. Murrell, M. Paladini, S. Rihs, N.C. Sturchio, F. Tassi, O. Vaselli 2002: Geochemistry of Quaternary travertines in the region north of Rome (Italy), structural, hydrologic and paleoclimatic implications. - Earth and Planetary Science Letters, 203, pp. 709-728.

Minissale, A. 2004: Origin, transport and discharge of $\mathrm{CO}_{2}$ in central Italy. - Earth-Science Reviews, 66/1-2, pp. 89-141.

Nelson, J. 1990: Experimental investigation of control on cementation on carbonates. - J. of the geological Society London, 147, pp. 949-958.

Ohmoto, H., R.O. Rye 1979: Isotopes of sulfur and carbon, pp. 509-567. - In: H.L. Barnes (Ed.): Geochemistry of Hydrothermal Ore Deposits. John Wiley, New York, 880 p. 
Panichi, C., E. Tongiorgi 1976: Carbon isotopic composition of $\mathrm{CO}_{2}$ from springs, fumaroles, mofettes and travertines of central and southern Italy: a preliminary prospection method of geothermal areas. - Proc. 2nd U. N. Symposium on the Development and Use of Geothermal Energy, San Francisco, pp. 815-825.

Pentecost, A. 1991: Springs that turn life into stone. - New Scientist, 21, pp. 42-44.

Pentecost, A. 1995: The Quaternary travertine deposits of Europe and Asia minor. - Quaternary Science Reviews, 14, pp. 1005-1028.

Pentecost, A. 1999: The origin and development of the travertines and associated thermal waters at Matlock Bath. Derbyshire. - Proceedings of the Geologists Association, 110, pp. 217-232.

Pentecost, A. 2005: Travertine. - Springer-Verlag, Berlin Heidelberg, pp. 445

Pentecost, A., H. Viles 1994: A review and reassessment of travertine classification. - Geographie physique et Quaternaire, 48, pp. 305-314.

Pentecost, A., S. Bayari, C. Yesertener 1997: Phototrophic microorganisms of the Pamukkale travertine, Turkey: Their distribution and influence on travertine deposition. Geomicrobiology Journal, 14, pp. 269-283.

Rainey, D.K., B. Jones 2007: Rapid cold water formation and recrystallization of relict bryophyte tufa at the Fall Creek cold springs, Alberta, Canada. - Canadian Journal of Earth Sciences, 44, pp. 889-909.

Renaut, R.W., CK. Morley, B. Jones 2002: Fossil hot-spring travertine in the Turkana Basin, northern Kenya; structure, facies and genesis. In: Renaut R.W., G.M. Ashle (Eds): Sedimentation in continental rifts. - Special Publication of Society of Sedimentary Geology, 73, pp. 123-141.

Sanders, J.E., G.M. Friedman 1967: Origin and occurrence of limestones. - In: Chilingar, G.V., H.J. Bissel, R.W. Fairbridge (Eds): Carbonate Rocks Developments in Sedimentology. Elsevier, Amsterdam, 9A, pp. 169-265.

Schweitzer, F., G. Scheuer 1995: Hungarian travertines. - Acta Universitas Szegediensis. Acta Geogr, 34, pp. 163-186.

Selim, H.H., G. Yanik 2009: Development of the Cambazli (Turgutlu/MANISA) fissure-ridge-type travertine and relationship with active tectonics Gediz Graben, Turkey. - Quaternary International, 199, pp. 157-163.

Shemshaki, A., Y. Mohammadi, A.R. Ghasemi 2008: Statistical analysis of physicochemical parameters of selected streams of the Central Alborz based on in situ testing. - Crust monitoring project, Geological Survey and Mining Exploration of Iran.

Shieh, Y.N., H.P. Taylor 1969: Oxygen and carbon isotope studies of contact metamorphism of carbonate rocks. - Journal of Petrology, 10, pp. 307-331.

Shipton Z.K., J.P. Evans, D. Kirschner, P.T. Kolesar, A.P. Williams, J.E. Heath 2004: Analyses of $\mathrm{CO}_{2}$ leakage through "low-permeability" faults from natural reservoirs in the Colorado Plateau, eastcentral Utah. - Journal of the Geological Society (London), Spec. Publ., 233, pp. 43-58.

Sierralta, M., S. Kele, F. Melcher, U. Hambach, J. Reinders, R. van Geldern, M. Frechen 2010: Characterisation and Uranium-series dating of Travertine from Süttő in Hungary. - Quaternary International, 222, pp. 178-193.

Siklósy, Z., A. Demény, Cs. Szabó, L. Korpás, K. Gálné Sólymos 2006: Petrographic and geochemical studies on the Upper Cretaceous travertine cone and red calcites (Vértes Mts., Hungary). Bulletin of the Hungarian Geological Society, 136/3, pp. 369-398. (In Hungarian.)

Spötl, C., Y. Dublyansky, M. Meyer, A. Mangini 2009: Identifying low-temperature hydrothermal karst and palaeowaters using stable isotopes: a case study from an alpine cave, Entrische Kirche, Austria. - International Journal of Earth Sciences (Geol Rundsch), 98, pp. 665-676.

Sunagawa, I. 1990: In situ observation of nucleation, growth and dissolution of crystals in ordinary temperature aqueous solutions and high temperature silicate solutions. - In: Marumo, F. (Ed.): Dynamic processes of material transport and transformation in the Earth's Interior. Terra Scientific Publishing Company, Tokyo, Japan, pp. 139-168.

Szöőr, Gy., É. Balázs, P. Sümeghy, Gy. Scheuer, F. Schweitzer, E. Hertelendi 1992: Thermoanalytical and isotope-geochemical study of the travertine in Hungary - with facies and stratigraphical 
evaluation). - In: Szöőr, Gy. (Ed.): Research studies on facies, palaeobiogeochemistry and palaeoecology, Debrecen, Hungary, pp. 93-107.

Tchalenko, J.S. 1974: Recent destructive earthquakes in the Central Alborz. - GSI, 29, pp. 97-116.

Tucker, M.E., V.P. Wright 1990: Carbonate sedimentology. - Blackwell Scientific Publications, London, UK.

Uysal, T., Y. Feng, J. Zhao, V. Isik, P. Nuriel, S.D. Golding 2009: Hydrothermal $\mathrm{CO}_{2}$ degassing in seismically active zones during the late Quaternary. - Chemical Geology, 265, pp. 442-454.

Viles, H.A., A.S. Goudie 1990: Tufas, travertines and allied carbonate deposits. - Progress in Physical Geography, 14, pp. 19-41.

Wyatt, A. (Ed.) 1986: Challinor's Dictionary of Geology (Sixth Edition). - University of Wales Press, Cardiff, $374 \mathrm{p}$.

Zentmyer, R., P.M. Myrow, D.L. Newell 2008: Travertine deposits from along the South Tibetan Fault System near Nyalam, Tibet. - Geological Magazine, 145, pp. 753-765. 